Article

\title{
Synthesis and Fluorescence Properties of a New Heterotrinuclear Co(II)-Ce(III)Complex Constructed from a bis(salamo)-Type Tetraoxime Ligand
}

\author{
Lu-Mei Pu ${ }^{1, *}$, Qing Zhao ${ }^{2}$, Ling-Zhi Liu ${ }^{2}$, Han Zhang ${ }^{2}$, Hai-Tao Long ${ }^{1}$ and Wen-Kui Dong ${ }^{2, *}$ (D) \\ 1 College of Science, Gansu Agricultural University, Lanzhou 730070, China; dapanji@163.com \\ 2 School of Chemical and Biological Engineering, Lanzhou Jiaotong University, Lanzhou 730070, China; \\ zq18215194507@163.com (Q.Z.); 1lz1009663202@126.com (L.-Z.L.); 13572510846@163.com (H.Z.) \\ * $\quad$ Correspondence: pulm@gsau.edu.cn (L.-M.P.); dongwk@126.com (W.-K.D.); Tel.: +86-931-493-8703 (W.-K.D.)
}

Academic Editor: Wolfgang Beck and Arnaud Gautier

Received: 27 February 2018; Accepted: 30 March 2018; Published: 31 March 2018

\begin{abstract}
Co}_{2}(\mathrm{~L}) \mathrm{Ce}(\mathrm{OAc})_{3}\left(\mathrm{CH}_{3} \mathrm{CH}_{2} \mathrm{OH}\right)\right] \cdot 1.5 \mathrm{CH}_{3} \mathrm{OH} \cdot 0.5 \mathrm{CH}_{2} \mathrm{Cl}_{2}$, a heterotrinuclear $\mathrm{Co}(\mathrm{II})-\mathrm{Ce}(\mathrm{III})$ bis(salamo)-type complex with a symmetric bi(salamo)-type ligand $\mathrm{H}_{4} \mathrm{~L}$ and an acyclic naphthalenediol moiety, was designed, synthesized and characterized by elemental analyses, FT-IR, UV-Vis and fluorescence spectroscopy and X-ray crystallography. The X-ray crystallographic investigation revealed the heterotrinuclear complex consisted of two $\mathrm{Co}(\mathrm{II})$ atoms, one Ce(III) atom, one $(\mathrm{L})^{4-}$ unit, three $\mu_{2}$-acetate ions, one coordinated ethanol molecule, one and half crystallization methanol molecule and half crystallization dichloromethane molecule. Two Co(II) atoms located in the $\mathrm{N}_{2} \mathrm{O}_{2}$ coordination spheres, are both hexacoordinated, with slightly distorted octahedral geometries. The $\mathrm{Ce}(\mathrm{III})$ atom is nine-coordinated and located in the $\mathrm{O}_{6}$ cavity possesses a single square antiprismatic geometry. In addition, supramolecular interactions exist in the $\mathrm{Co}$ (II)-Ce(III) complex. Two infinite 2D supramolecular structures are built via intermolecular $\mathrm{O}-\mathrm{H} \cdots \mathrm{O}, \mathrm{C}-\mathrm{H} \cdots \mathrm{O}$ and $\mathrm{C}-\mathrm{H} \cdots \pi$ interactions, respectively.
\end{abstract}

Keywords: bi(salamo)-type ligand; heterotrinuclear complex; synthesis; crystal structure; fluorescence property

\section{Introduction}

Salen $(N, N$-disalicylideneethylenediamine) is a versatile important compound that has been widely used in coordination chemistry and organometallic chemistry [1-8]. On the one hand, salen-type compounds are tetradentate ligands with a $\mathrm{N}_{2} \mathrm{O}_{2}$ coordination environment that can usually coordinate with transition metal ions to afford diverse metal complexes. On the other hand, a number of salen-type metal complexes have already been synthesized to study their structures and applied in various fields for their magnetic properties [9-14], catalytic action [15,16], electrochemistry [17,18], in biological systems [19-28], supramolecular architectures [29-37], their luminescent properties [38-44], and in optical sensors [45] and nonlinear optical materials [46].

More recently, salamo-type ligands [47-56] using an $\mathrm{O}$-alkyloxime $\left(-\mathrm{CH}=\mathrm{N}-\mathrm{O}-\left(\mathrm{CH}_{2}\right)_{n}-\mathrm{O}-\right.$ $\mathrm{N}=\mathrm{CH}-$ ) have been reported. In our previous studies on salamo-type metal complexes, we exchanged salicylaldehyde for its derivatives to obtain some new salamo-type complexes with different structures. Our research group is focused on the synthesis and study of $3 \mathrm{~d}-4 \mathrm{f}$ heterometallic salamo-type complexes [14,16,49].

Based on these points of view, we have now designed and synthesized a symmetric bi(salamo)-type ligand $\mathrm{H}_{4} \mathrm{~L}$ and its corresponding heterotrinuclear $\mathrm{Co}(\mathrm{II})-\mathrm{Ce}(\mathrm{III}) 3 \mathrm{~d}-4 \mathrm{f}$ complex 
$\left[\mathrm{Co}_{2}(\mathrm{~L}) \mathrm{Ce}(\mathrm{OAc})_{3}\left(\mathrm{CH}_{3} \mathrm{CH}_{2} \mathrm{OH}\right)\right] \cdot 1.5 \mathrm{CH}_{3} \mathrm{OH} \cdot 0.5 \mathrm{CH}_{2} \mathrm{Cl}_{2}$. The structure of $\mathrm{H}_{4} \mathrm{~L}$ is depicted in Figure 1. Furthermore, the structure and fluorescence properties of the $\mathrm{Co}(\mathrm{II})-\mathrm{Ce}(\mathrm{III})$ complex were studied.<smiles>COc1cccc(/C=N/OCCO/N=C/c2cccc(OC)c2O)c1O</smiles>

Figure 1. Structural representation of the ligand $\mathrm{H}_{4} \mathrm{~L}$.

\section{Results and Discussion}

\subsection{IR Spectra}

The IR spectra of $\mathrm{H}_{4} \mathrm{~L}$ and its corresponding $\mathrm{Co}(\mathrm{II})-\mathrm{Ce}(\mathrm{III})$ complex exhibited various bands in the $4000-400 \mathrm{~cm}^{-1}$ region. The FT-IR spectrum and data of the ligand $\mathrm{H}_{4} \mathrm{~L}$ and its corresponding $\mathrm{Co}(\mathrm{II})-\mathrm{Ce}(\mathrm{III})$ complex are given in Figure 2 and Table 1.

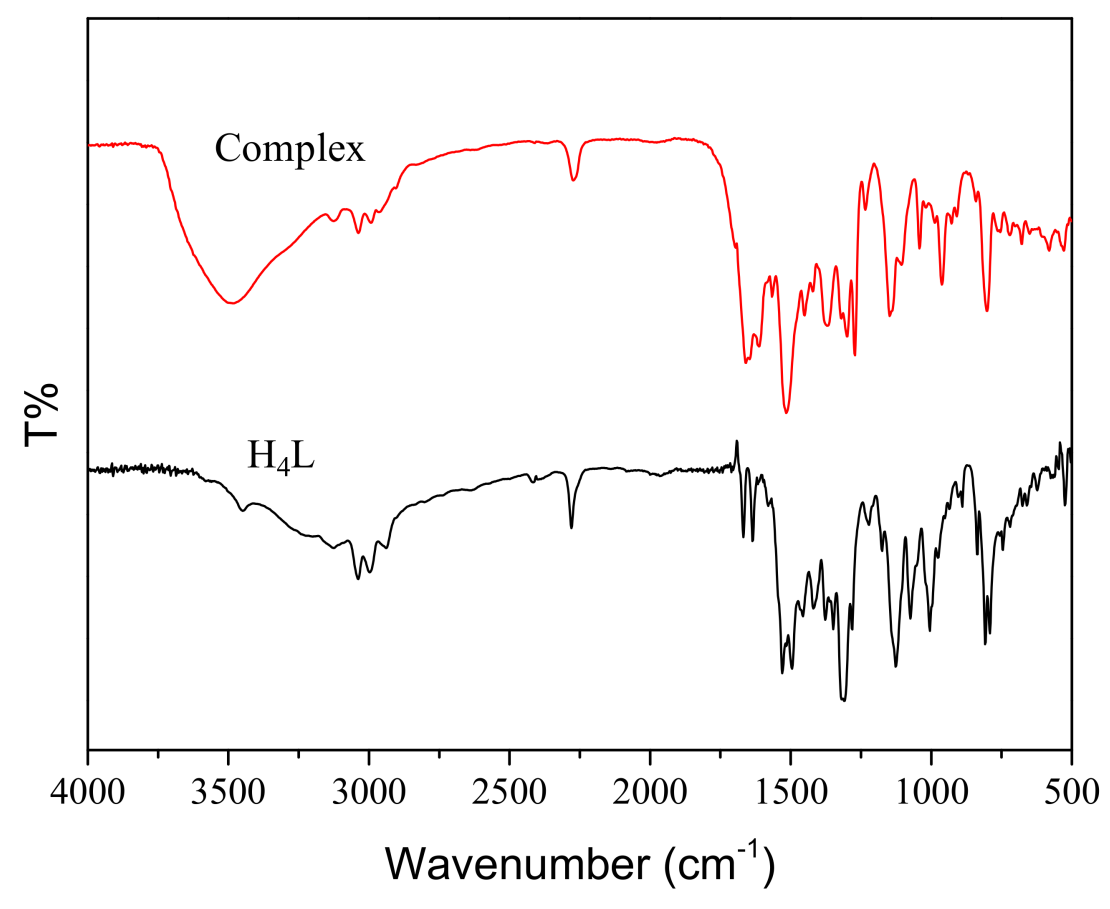

Figure 2. IR spectra of the ligand $\mathrm{H}_{4} \mathrm{~L}$ and its complex.

Table 1. Selected FT-IR bands for $\mathrm{H}_{4} \mathrm{~L}$ and its $\mathrm{Co}(\mathrm{II})-\mathrm{Ce}(\mathrm{III})$ complex $\left(\mathrm{cm}^{-1}\right)$.

\begin{tabular}{cccc}
\hline Compound & $v(\mathbf{O}-\mathrm{H})$ & $v(\mathrm{C}=\mathrm{N})$ & $v(\mathrm{Ar}-\mathrm{O})$ \\
\hline $\mathrm{H}_{4} \mathrm{~L}$ & 3169 & 1612 & 1255 \\
Complex & - & 1623 & 1239 \\
\hline
\end{tabular}


A $C=N$ stretching vibration band was observed at $1612 \mathrm{~cm}^{-1}$ in the IR spectrum of $\mathrm{H}_{4} \mathrm{~L}$. Upon complex formation, the strong characteristic $\mathrm{C}=\mathrm{N}$ vibration band of the $\mathrm{Co}(\mathrm{II})-\mathrm{Ce}(\mathrm{III})$ complex appeared at $1623 \mathrm{~cm}^{-1}$, which is slightly red-shifted in comparison to the free ligand $\mathrm{H}_{4} \mathrm{~L}$ and is attributed to coordination of the nitrogen atoms of the $\mathrm{C}=\mathrm{N}$ group and the metal(II) atoms [57]. The Ar-O stretching vibration band is detected in a range of $1220-1260 \mathrm{~cm}^{-1}$. In the free ligand $\mathrm{H}_{4} \mathrm{~L}$ the characteristic Ar-O group absorption appeared at $1255 \mathrm{~cm}^{-1}$, a ca. $16 \mathrm{~cm}^{-1}$ shift to a lower frequency showing that the $\mathrm{M}-\mathrm{O}$ bonds are formed between the metal atoms and the oxygen atoms from methoxy and phenolic groups of the free ligand $H_{4} L$ [58]. The above facts are consistent with the results determined by $\mathrm{X}$-ray diffraction.

\subsection{UV-Vis Absorption Spectra}

In many studies, UV-Vis absorption spectra have been utilized to study lanthanide complexes. In this study, the UV-Vis spectra of the free ligand $\mathrm{H}_{4} \mathrm{~L}$ in $\mathrm{CHCl}_{3}: \mathrm{CH}_{3} \mathrm{OH}(1: 1)\left(c=2.5 \times 10^{-5} \mathrm{~mol} \mathrm{~L}^{-1}\right)$ with its corresponding $\mathrm{Co}(\mathrm{II})-\mathrm{Ce}(\mathrm{III})$ complex in $\mathrm{CH}_{3} \mathrm{OH}: \mathrm{H}_{2} \mathrm{O}(10: 1)\left(c=1 \times 10^{-3} \mathrm{~mol} \mathrm{~L}^{-1}\right)$ were collected in the range of $250-550 \mathrm{~nm}$. In the absorption spectrum of the free ligand $\mathrm{H}_{4} \mathrm{~L}$, there are four consecutive absorption peaks at ca. 269, 342, 360 and $375 \mathrm{~nm}$. The absorption peak at $269 \mathrm{~nm}$ can be assigned to the $\pi-\pi^{*}$ transition of the benzene rings. The other three absorption peaks can be attributed to the $\pi-\pi^{*}$ transition of the oxime groups [57].

In the UV-Vis titration experiment, it can be clearly seen that the gradual addition of $\mathrm{Co}(\mathrm{OAc})_{2}$ solution caused absorption peak changes. Compared to the free ligand $\mathrm{H}_{4} \mathrm{~L}$, the absorption peaks are bathochromically shifted [59]. This phenomenon is due to the coordination of $\mathrm{H}_{4} \mathrm{~L}$ with the $\mathrm{Co}$ (II) ions. Upon addition of $\mathrm{Co}$ (II) ions, the absorbance of the solution first increases. When $\mathrm{Co}(\mathrm{II})$ ions were added in excess of three equiv, the absorbance of the solution no longer changed. The spectroscopic titration clearly showed the formation of a 1:3 Co(II) complex (Figure 3a).

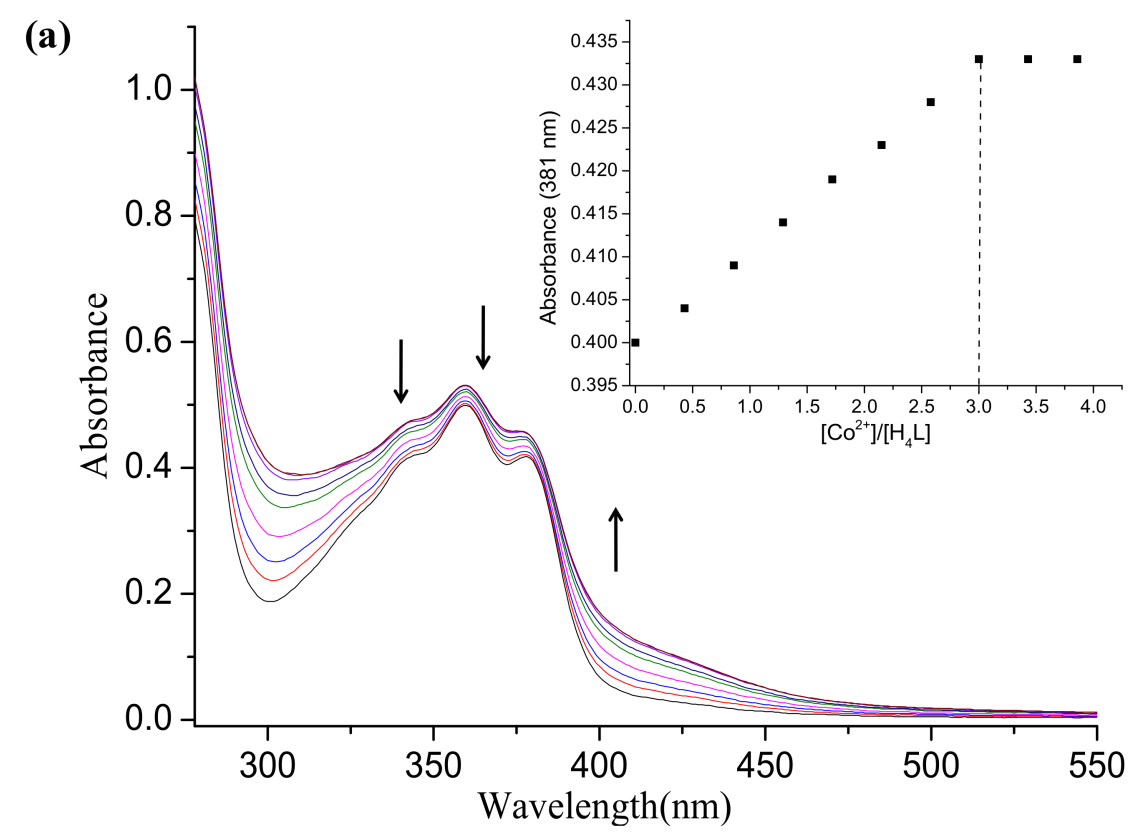

Figure 3. Cont. 


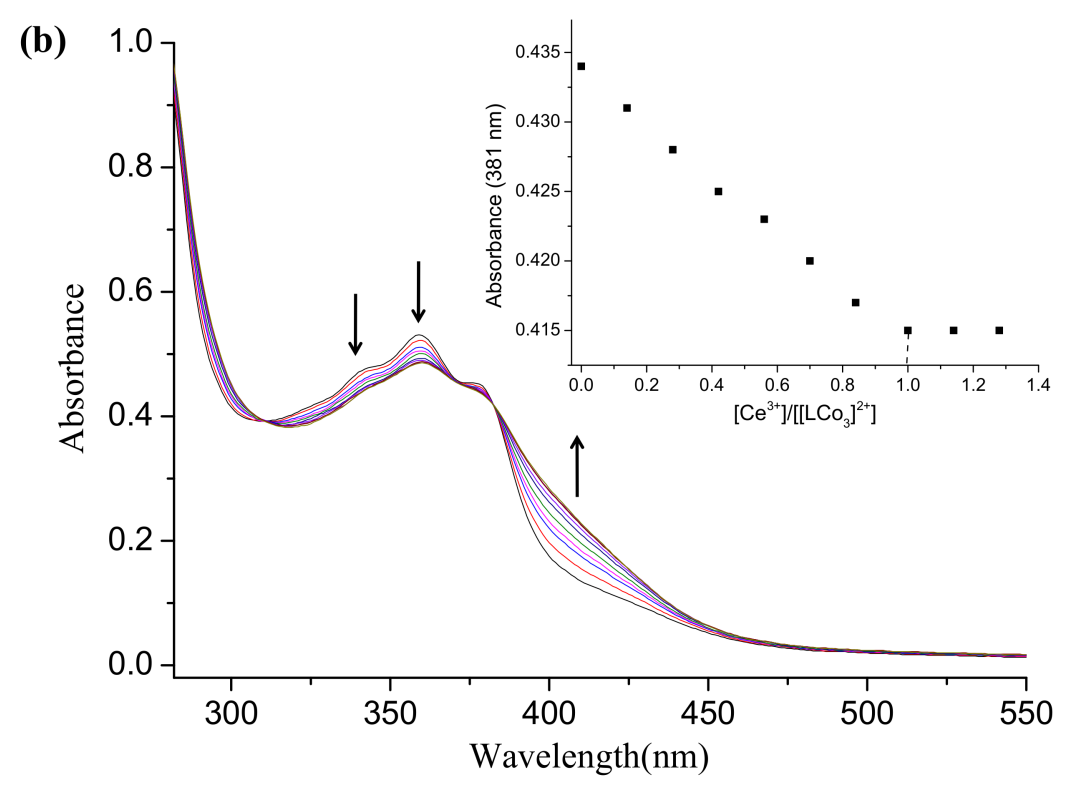

Figure 3. (a) UV-Vis spectral changes of the $\mathrm{H}_{4} \mathrm{~L}\left(2.5 \times 10^{-5} \mathrm{M}\right)$ on addition of $\mathrm{Co}(\mathrm{II})\left(1.0 \times 10^{-3} \mathrm{M}\right)$ ions; (b) UV-Vis spectral changes of the $\left[\mathrm{LCo}_{3}\right]^{2+}$ on addition of $\mathrm{Ce}(\mathrm{III})\left(1.0 \times 10^{-3} \mathrm{M}\right)$ ions.

The color of the solution changed unconspicuously when Ce(III) ions were added. Then, upon addition of 1 equiv of Ce(II) ions, the absorbance changed and showed three isoabsorptive points at about 313,365 and $380 \mathrm{~nm}$. The spectroscopic titration clearly exhibited that the ratio of the replacement reaction stoichiometry is $1: 1$ and is shown in Figure $3 b$.

The importance of the coordination of $\mathrm{OAc}^{-}$was confirmed by the following experiment. A 1:3:1 mixture of $\mathrm{H}_{4} \mathrm{~L}, \mathrm{Co}\left(\mathrm{NO}_{3}\right)_{2}$ and $\mathrm{Ce}\left(\mathrm{NO}_{3}\right)_{3}$ displayed an absorption spectrum identical to that of $\mathrm{H}_{4} \mathrm{~L}$, indicating no complexation. Spectrophotometric titration of the mixture with KOAc showed that nine equiv of KOAc were required to convert the mixture to $\left[\mathrm{LCo}_{2} \mathrm{Eu}(\mathrm{OAc})_{3}\right]$. The nine equiv of OAc-consists of six for deprotonation and three for coordination to the trinuclear core.

\subsection{Crystal Structure Description}

The crystal structure of the Co(II)-Ce(III) complex was determined by X-ray crystallography and is shown in Figure 4.

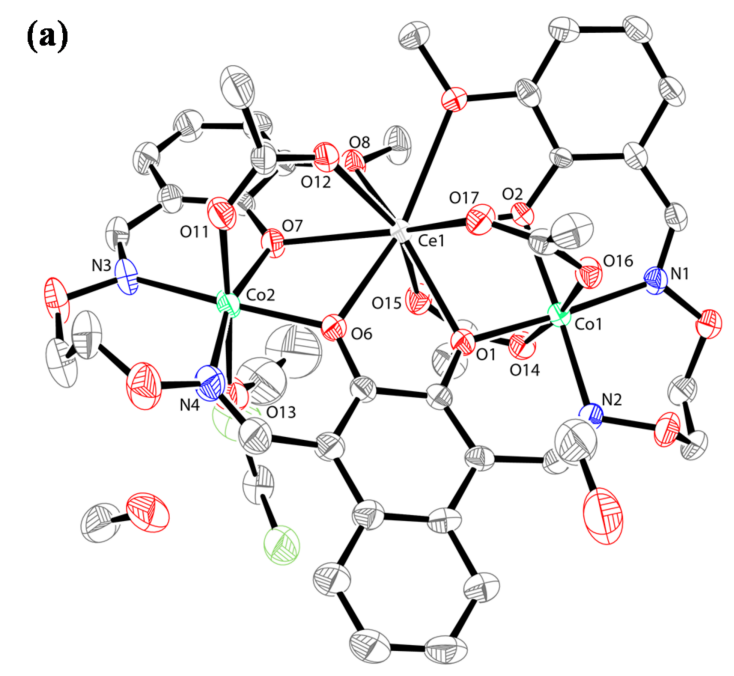

Figure 4. Cont. 


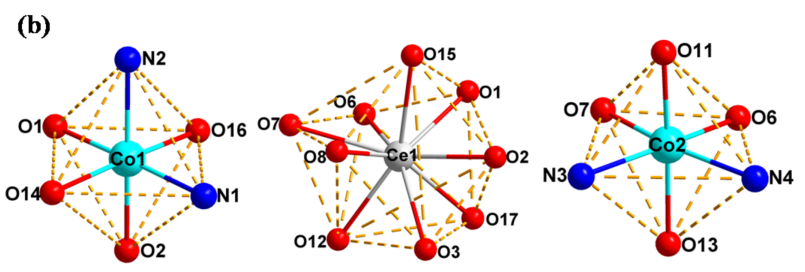

Figure 4. (a) View of the molecular structure of the Co(II)-Ce(III) complex; (b) Coordination polyhedrons for $\mathrm{Co}(\mathrm{II})$ and $\mathrm{Ce}(\mathrm{III})$ atoms.

X-ray crystallographic analysis revealed that the Co(II)-Ce(III) complex crystallizes in a triclinic system, space group of $P-1$, possessing a symmetric trinuclear structure. The $\mathrm{Co}$ (II)-Ce(III) complex consists of two $\mathrm{Co}$ (II) atoms, one $\mathrm{Ce}(\mathrm{III})$ atom, one $(\mathrm{L})^{4-}$ unit, three $\mu_{2}$-acetate ions, one coordinated ethanol molecule, one and half crystallization methanol molecules and half crystallization dichloromethane molecule. As shown in Figure 4, we can see that the coordination ratio of the ligand (L) ${ }^{4-}$ unit to metal atoms (Co(II) and Ce(III)) in the Co(II)-Ce(III) complex is 1:2:1 [60,61]. Meanwhile, the terminal Co(II) atoms ( $\mathrm{Co} 1$ and $\mathrm{Co} 2)$ are located in the $\mathrm{N}_{2} \mathrm{O}_{2}$ compartments and they are both hexa-coordinated with slightly distorted octahedral geometries [62-64]. Differently, the Co1 atom is bonded to two $\mu_{2}$-acetate ions (O14 and $\mathrm{O} 16)$, the nitrogen atoms ( $\mathrm{N} 1$ and $\mathrm{N} 2)$ and oxygen atoms (O1 and $\mathrm{O} 2)$ of the oxime and phenolic groups. The $\mathrm{Co} 2$ atom is coordinated the nitrogen atoms ( $\mathrm{N} 3$ and $\mathrm{N} 4)$ and oxygen atoms (O6 and O7) of the oxime and phenolic groups, one $\mu_{2}$-acetate oxygen atom (O11) and one oxygen atom (O13) from the coordinated ethanol molecule. The central $\mathrm{O}_{6}$ site $(\mathrm{O} 1, \mathrm{O} 2, \mathrm{O} 3, \mathrm{O} 6, \mathrm{O} 7$ and O8) was occupied by one Ce(III) atom coordinating to three oxygen atoms (O12, O15 and O17) of three $\mu_{2}$-acetate ions. Hence, the $\mathrm{Ce}(\mathrm{III})$ atom is nine-coordinated with a single square antiprismatic geometry. In the crystal structure of the $\mathrm{Co}$ (II)-Ce(III) complex, three $\mu_{2}$-acetate ions bridge $\mathrm{Co}$ (II) and $\mathrm{Ce}$ (III) atoms in a familiar $\mu_{2}$-fashion mode. The high coordination number of $\mathrm{Ce}$ (III) atom is determined by its longer ionic radius and smaller winding angles. The $\mathrm{Ce}-\mathrm{O}$ bond distances of the four phenolic oxygen $(\mathrm{O} 1, \mathrm{O} 2, \mathrm{O} 6$ and $\mathrm{O} 7)$ atoms from the completely deprotonated $(\mathrm{L})^{4-}$ unit are in the range of 2.421(4) $-2.523(3) \AA$ and the $\mathrm{Ce}-\mathrm{O}$ bond distances of the methoxy groups are about Ce1-O3, 2.688(4) and Ce1-O8 2.655(4) $\AA$, which are clearly shorter than later. The crystallographic data and structural refinement paramenters are summarized in Table 2. Selected bond lengths and angles of the Co(II)-Ce(III) complex are listed in Table 3.

Table 2. Crystallographic data and structural refinement paramenters for the Co(II)-Ce(III) complex.

\begin{tabular}{|c|c|}
\hline Formula & $\mathrm{C}_{42} \mathrm{H}_{50} \mathrm{ClCo}_{2} \mathrm{CeN}_{4} \mathrm{O}_{18.50}$ \\
\hline Formula weight, $\mathrm{g} \cdot \mathrm{mol}^{-1}$ & 1200.29 \\
\hline Temperature, $\mathrm{K}$ & 293.66(10) \\
\hline Wavelength, $\AA$ & 0.71073 \\
\hline Crystal system & Triclinic \\
\hline Space group & $P-1$ \\
\hline$a, \AA$ & $12.0521(5)$ \\
\hline$b, \AA$ & $13.7804(5)$ \\
\hline$c, \AA$ & $15.2909(4)$ \\
\hline$\alpha,{ }^{\circ}$ & $95.678(3)$ \\
\hline$\beta, \circ$ & $99.471(3)$ \\
\hline$\gamma,{ }^{\circ}$ & $90.210(3)$ \\
\hline Volume, $\AA^{3}$ & 2492.13(15) \\
\hline Z & 2 \\
\hline Calculated density, $\mathrm{mg} \cdot \mathrm{m}^{-3}$ & 1.600 \\
\hline Absorption coefficient, $\mathrm{mm}^{-1}$ & 1.685 \\
\hline$F(000)$ & 1214 \\
\hline$\theta$ range for data collection, ${ }^{\circ}$ & $3.390-25.677^{\circ}$ \\
\hline$h / k / l(\min , \max )$ & $-12,14 /-16,16 /-18,18$ \\
\hline Reflections collected & 17180 \\
\hline
\end{tabular}


Table 2. Cont.

\begin{tabular}{|c|c|}
\hline Independent reflections & 9641 \\
\hline$R_{\text {int }}$ & 0.034 \\
\hline Completeness to $\theta=26.32$ & $99.78 \%$ \\
\hline Data/restraints/parameters & $9641 / 60 / 649$ \\
\hline Final R indices $[\mathrm{I}>2 \sigma(\mathrm{I})]^{\mathrm{a}}[\mathrm{I}>2 \sigma(\mathrm{I})]$ & $R_{1}=0.0519, w R_{2}=0.1377$ \\
\hline $\mathrm{R}$ indices (all data) $\mathrm{b}$ & $R_{1}=0.0693, w R_{2}=0.1537$ \\
\hline Goodness-of-fit for $\mathrm{F}^{2 \mathrm{c}}$ & 1.020 \\
\hline Largest differences peak and hole $\left(\mathrm{e} \AA^{-3}\right)$ & 1.130 and -1.300 \\
\hline
\end{tabular}

Table 3. Selected bond lengths $(\AA)$ and angles $\left({ }^{\circ}\right)$ for the Co(II)-Ce(III) complex.

\begin{tabular}{|c|c|c|c|c|c|}
\hline \multicolumn{3}{|c|}{ Bonds Lengths (̊̊) } & \multicolumn{3}{|c|}{ Bonds Lengths (̊̊) } \\
\hline Co1-O1 & $2.018(3)$ & $\mathrm{Co} 1-\mathrm{O} 2$ & $2.081(4)$ & Co1-O14 & $2.088(4)$ \\
\hline Co1-O16 & $2.123(4)$ & Co1-N1 & $2.095(5)$ & Co1-N2 & $2.116(4)$ \\
\hline $\mathrm{Co} 2-\mathrm{O} 6$ & $2.021(4)$ & $\mathrm{Co} 2-\mathrm{O} 7$ & $2.052(4)$ & $\mathrm{Co} 2-\mathrm{O} 11$ & $2.058(5)$ \\
\hline $\mathrm{Co} 2-\mathrm{O} 13$ & $2.168(6)$ & $\mathrm{Co} 2-\mathrm{N} 3$ & $2.123(5)$ & $\mathrm{Co} 2-\mathrm{N} 4$ & $2.139(7)$ \\
\hline Ce1-O1 & $2.421(4)$ & $\mathrm{Ce} 1-\mathrm{O} 2$ & $2.461(3)$ & $\mathrm{Ce} 1-\mathrm{O} 3$ & $2.688(4)$ \\
\hline Ce1-O6 & $2.467(4)$ & Ce1-O7 & $2.523(3)$ & $\mathrm{Ce} 1-\mathrm{O} 8$ & $2.655(4)$ \\
\hline $\mathrm{Ce} 1-\mathrm{O} 12$ & $2.437(5)$ & Ce1-O15 & $2.528(5)$ & Ce1-O17 & $2.526(4)$ \\
\hline \multicolumn{3}{|c|}{ Angle $\left({ }^{\circ}\right)$} & \multicolumn{3}{|c|}{ Angle $\left({ }^{\circ}\right)$} \\
\hline $\mathrm{O} 1-\mathrm{Co} 1-\mathrm{O} 2$ & $90.51(15)$ & O1-Co1-O14 & $87.26(16)$ & O1-Co1-O16 & $88.60(16)$ \\
\hline O1-Co1-N1 & $176.65(19)$ & O1-Co1-N2 & 83.73(17) & O2-Co1-O14 & $88.61(15)$ \\
\hline O2-Co1-O14 & $88.61(15)$ & O2-Co1-O16 & $85.93(15)$ & O2-Co1-N1 & 86.51(17) \\
\hline O2-Co1-N2 & $171.58(16)$ & O14-Co1-O16 & $173.12(17)$ & O14-Co1-N1 & $94.18(18)$ \\
\hline O14-Co1-N2 & $97.21(18)$ & O16-Co1-N1 & $89.67(18)$ & O16-Co1-N2 & 87.79(18) \\
\hline N1-Co1-N2 & $99.1(2)$ & O1-Ce1-O2 & $73.22(12)$ & O1-Ce1-O3 & $128.52(12)$ \\
\hline O1-Ce1-O6 & $62.41(11)$ & O1-Ce1-O7 & $115.41(12)$ & O1-Ce1-O8 & $136.97(13)$ \\
\hline O1-Ce1-O12 & $129.53(13)$ & O1-Ce1-O15 & $68.24(13)$ & O1-Ce1-O17 & $69.66(13)$ \\
\hline O2-Ce1-O3 & $60.44(13)$ & O2-Ce1-O6 & $135.35(13)$ & O2-Ce1-O7 & $147.78(12)$ \\
\hline $\mathrm{O} 2-\mathrm{Ce} 1-\mathrm{O} 8$ & $91.55(11)$ & O2-Ce1-O12 & $130.03(14)$ & O2-Ce1-O15 & 71.51(13) \\
\hline O2-Ce1-O17 & $72.66(13)$ & O3-Ce1-O6 & $151.91(15)$ & O3-Ce1-O7 & $115.69(13)$ \\
\hline O3-Ce1-O8 & $68.54(13)$ & O3-Ce1-O12 & $74.57(14)$ & O3-Ce1-O15 & $112.71(14)$ \\
\hline O3-Ce1-O17 & $75.97(14)$ & O6-Ce1-O7 & $64.67(13)$ & O6-Ce1-O8 & $124.04(12)$ \\
\hline O6-Ce1-O12 & $79.85(14)$ & O6-Ce1-O15 & $95.34(15)$ & O6-Ce1-O17 & $87.10(15)$ \\
\hline O7-Ce1-O12 & $70.43(14)$ & O7-Ce1-O8 & $60.38(11)$ & O7-Ce1-O15 & $82.89(13)$ \\
\hline O7-Ce1-O17 & $139.42(13)$ & O8-Ce1-O12 & $91.27(14)$ & O8-Ce1-O15 & $68.78(14)$ \\
\hline O8-Ce1-O17 & $144.42(13)$ & O12-Ce1-O15 & $152.40(15)$ & O12-Ce1-O17 & $76.59(15)$ \\
\hline O15-Ce1-O17 & $130.63(14)$ & & & & \\
\hline
\end{tabular}

\subsection{Supramolecular Interactions}

Notably, supramolecular interactions exist in the Co(II)-Ce(III) complex. The hydrogen bonds and $\mathrm{C}-\mathrm{H} \cdots \pi$ stacking interactions are listed in Table 4.

Table 4. Hydrogen bonds $(\AA, \mathrm{deg})$ and $\mathrm{C}-\mathrm{H} \cdots \pi$ stacking interactions for the Co(II)-Ce(III) complex.

\begin{tabular}{|c|c|c|c|c|c|}
\hline $\mathrm{D}-\mathrm{H} \cdots \mathrm{A}$ & $d(D-H)$ & $\mathrm{d}(\mathrm{H} \cdots \mathrm{A})$ & $d(D \cdots A)$ & $\angle \mathrm{DHA}$ & Symmetry Code A \\
\hline C9-H9B $\cdots$ O14 & 0.97 & 2.32 & $3.249(8)$ & 161 & \\
\hline 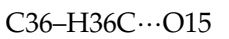 & 0.96 & 2.20 & $2.879(16)$ & 126 & \\
\hline $\mathrm{C} 23-\mathrm{H} 23 \mathrm{~B} \cdots \mathrm{N} 4$ & 0.97 & 2.46 & $2.865(11)$ & 105 & \\
\hline $\mathrm{C} 24-\mathrm{H} 24 \mathrm{~B} \cdots \mathrm{N} 3$ & 0.97 & 2.56 & $2.957(11)$ & 104 & \\
\hline $\mathrm{O} 13-\mathrm{H} 13 \cdots \mathrm{O} 18$ & 0.87 & 1.88 & $2.733(18)$ & 170 & $x, y, 1+z$ \\
\hline O19-H19A …O16 & 0.82 & 2.05 & $2.834(9)$ & 160 & $-\mathrm{x},-\mathrm{y}, 1-\mathrm{z}$ \\
\hline C34-H34A …Cl1 & 0.96 & 2.76 & $3.446(16)$ & 129 & $-1+x, y, z$ \\
\hline C36-H36А …Cl1 & 0.96 & 2.34 & $2.955(17)$ & 121 & $x, y, 1+z$ \\
\hline C41-H41B $\cdots \mathrm{O} 17$ & 0.97 & 2.38 & $3.345(16)$ & 173 & $1+x, y, z$ \\
\hline C24-H24A …g1 & & 2.97 & $3.599(10)$ & 124 & $-\mathrm{x},-\mathrm{y},-\mathrm{z}$ \\
\hline
\end{tabular}

Symmetry codes: Cg1 for the Co(II)-Ce(III) complex is the centroid of C27-C32 atoms. 
In the crystal structure of the $\mathrm{Co}(\mathrm{II})-\mathrm{Ce}(\mathrm{III})$ complex, there are four significant intramolecular

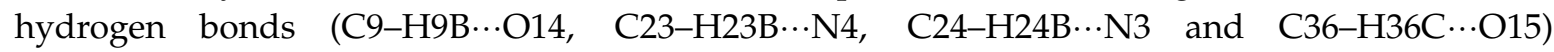
(Figure 5) [65-69]. As illustrated in Figures 6 and 7, three pairs of intermolecular hydrogen

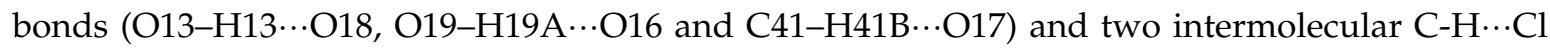
interactions (C34-H34A… Cl1 and C36-H36A…C11) are formed, respectively [70-74]. Especially, an infinite $2 \mathrm{D}$ supramolecular structure are interlinked by one significant $\mathrm{C}-\mathrm{H} \cdots \pi$ interactions (C24-H24A ... Cg1 (C27-C32)) and is shown in Figure 8.

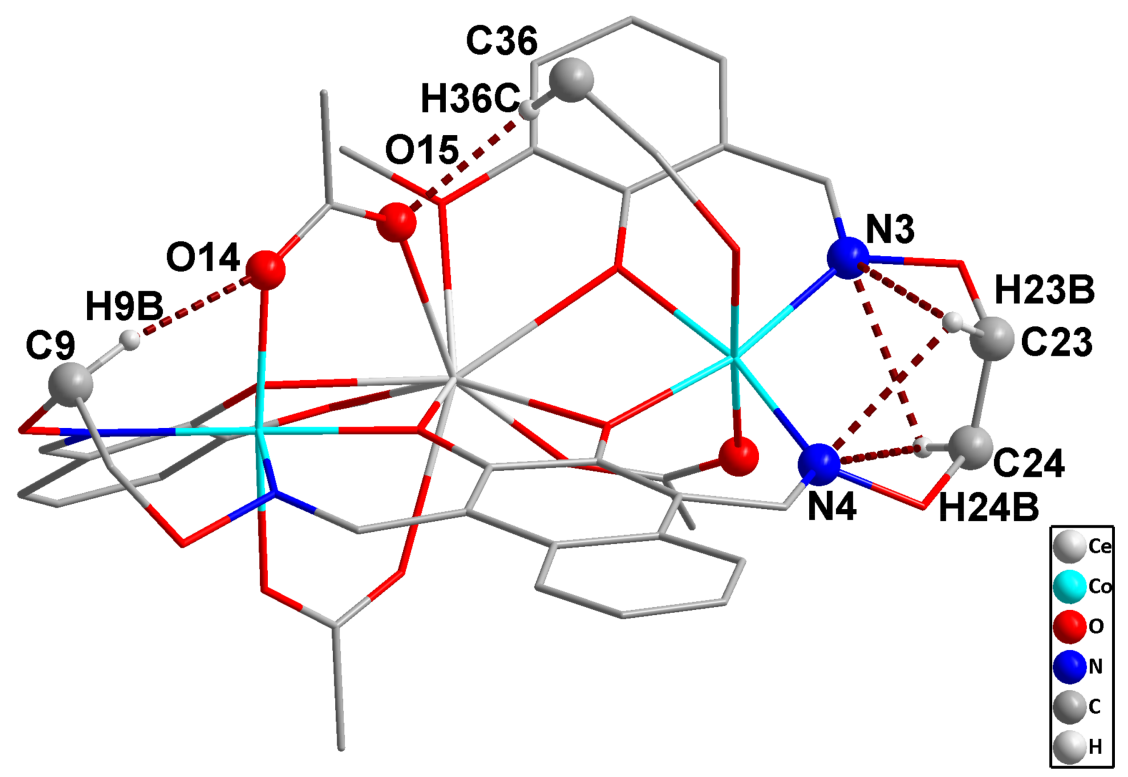

Figure 5. View of the intramolecular hydrogen bonds for the Co(II)-Ce(III) complex.

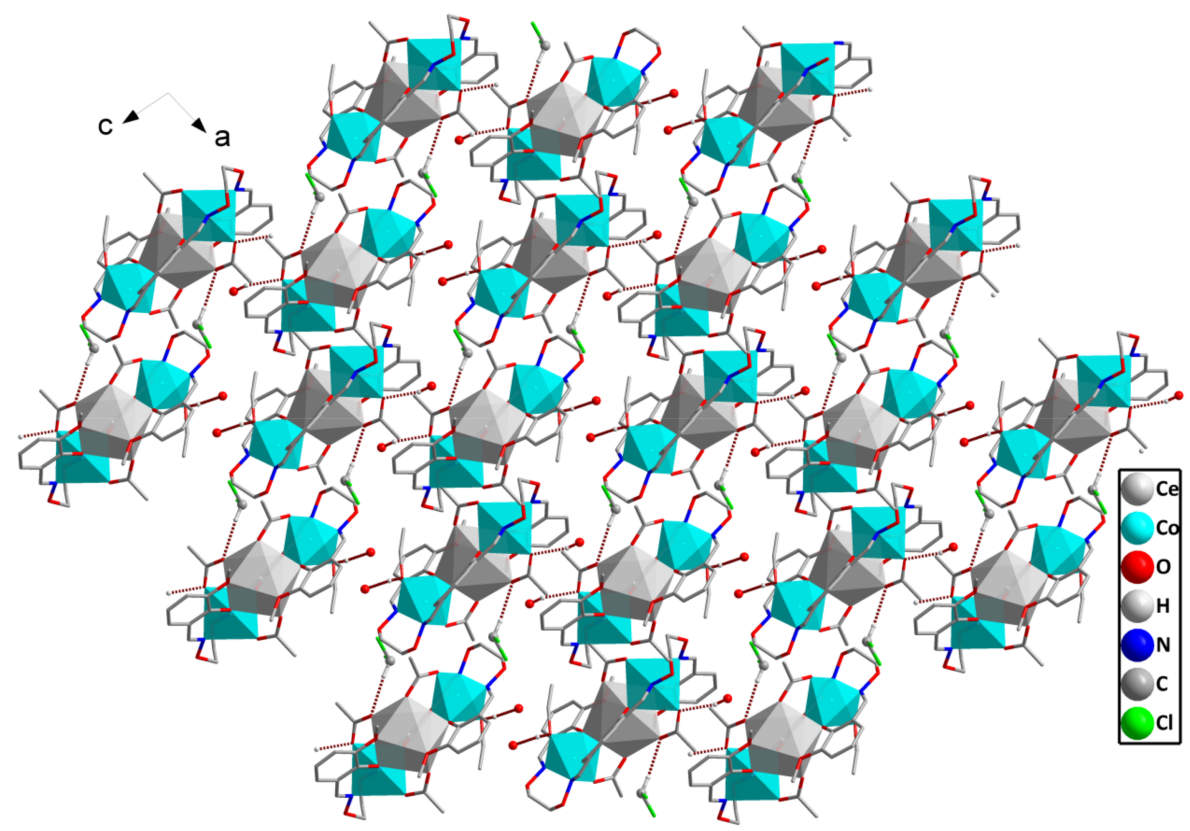

Figure 6. View of 2D supramolecular structure by the intermolecular $\mathrm{O}-\mathrm{H} \cdots \mathrm{O}$ and $\mathrm{C}-\mathrm{H} \cdots \mathrm{O}$ interactions of the $\mathrm{Co}(\mathrm{II})-\mathrm{Ce}(\mathrm{III})$ complex. 


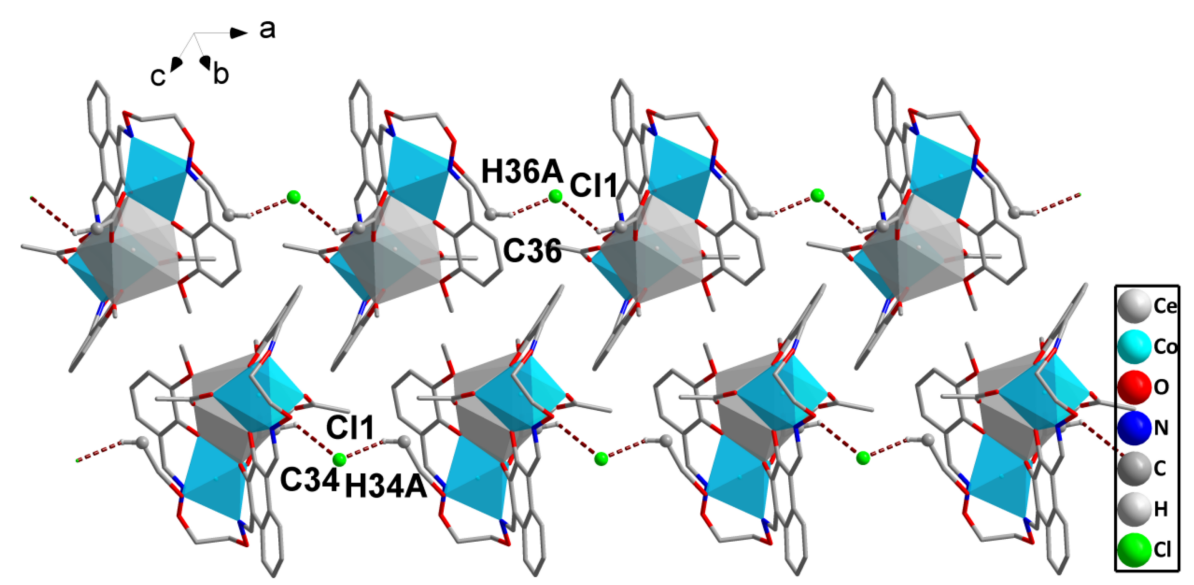

Figure 7. View of $1 \mathrm{D}$ supramolecular structure by the intermolecular $\mathrm{C}-\mathrm{H} \cdots \mathrm{Cl}$ interactions of the $\mathrm{Co}(\mathrm{II})-\mathrm{Ce}(\mathrm{III})$ complex.

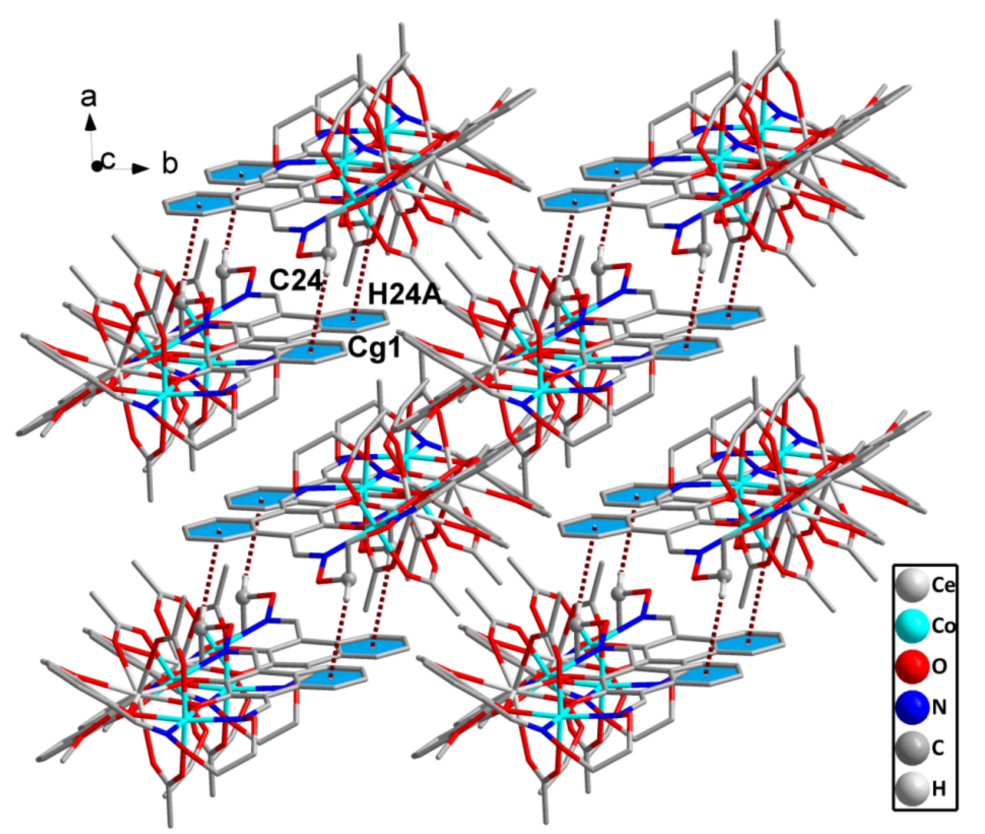

Figure 8. View of $2 \mathrm{D}$ supramolecular structure by $\mathrm{C}-\mathrm{H} \cdots \pi$ interaction of the $\mathrm{Co}(\mathrm{II})-\mathrm{Ce}(\mathrm{III})$ complex.

\subsection{Fluorescence Tests}

Recently, synthesis of several examples of lanthanide complexes of salamo-type ligands to study their luminescence properties have been reported $[75,76]$. The fluorescence emission spectra of $\mathrm{H}_{4} \mathrm{~L}$ in $\mathrm{CHCl}_{3}: \mathrm{CH}_{3} \mathrm{OH}$ solution and its corresponding $\mathrm{Co}(\mathrm{II})-\mathrm{Ce}(\mathrm{III})$ complex in methanol solution were investigated at room temperature. In the fluorescence titration experiment, the emission spectrum of the free ligand $\mathrm{H}_{4} \mathrm{~L}$ exhibited broad visible photoluminescence with maximum emission at ca. $416 \mathrm{~nm}$ upon excitation at $340 \mathrm{~nm}$ (Figure 9a). When Co(II) ions was added, the fluorescence emission intensity quenches. The fluorescence emission intensity of the solution no longer changed after the Co(II) ions was added in excess of three equiv. The spectroscopic titration indicated that the stoichiometric ratio between $\mathrm{Co}(\mathrm{II})$ and the ligand $\mathrm{H}_{4} \mathrm{~L}$ is 3:1 (Figure 9b). Then, the fluorescence intensity enhances upon addition of Ce(III) ions and showed a maximum at ca. $433 \mathrm{~nm}$ upon excitation at $341 \mathrm{~nm}$ (Figure 10a). When the amount of $\mathrm{Ce}(\mathrm{III})$ ions reaches one equiv, the fluorescence emission intensity of the solution becomes stable. Obviously, the spectroscopic titration indicated that the ratio of the replacement reaction was 1:1 (Figure 10b), which obtained the same conclusion with UV-Vis titration experiments. 

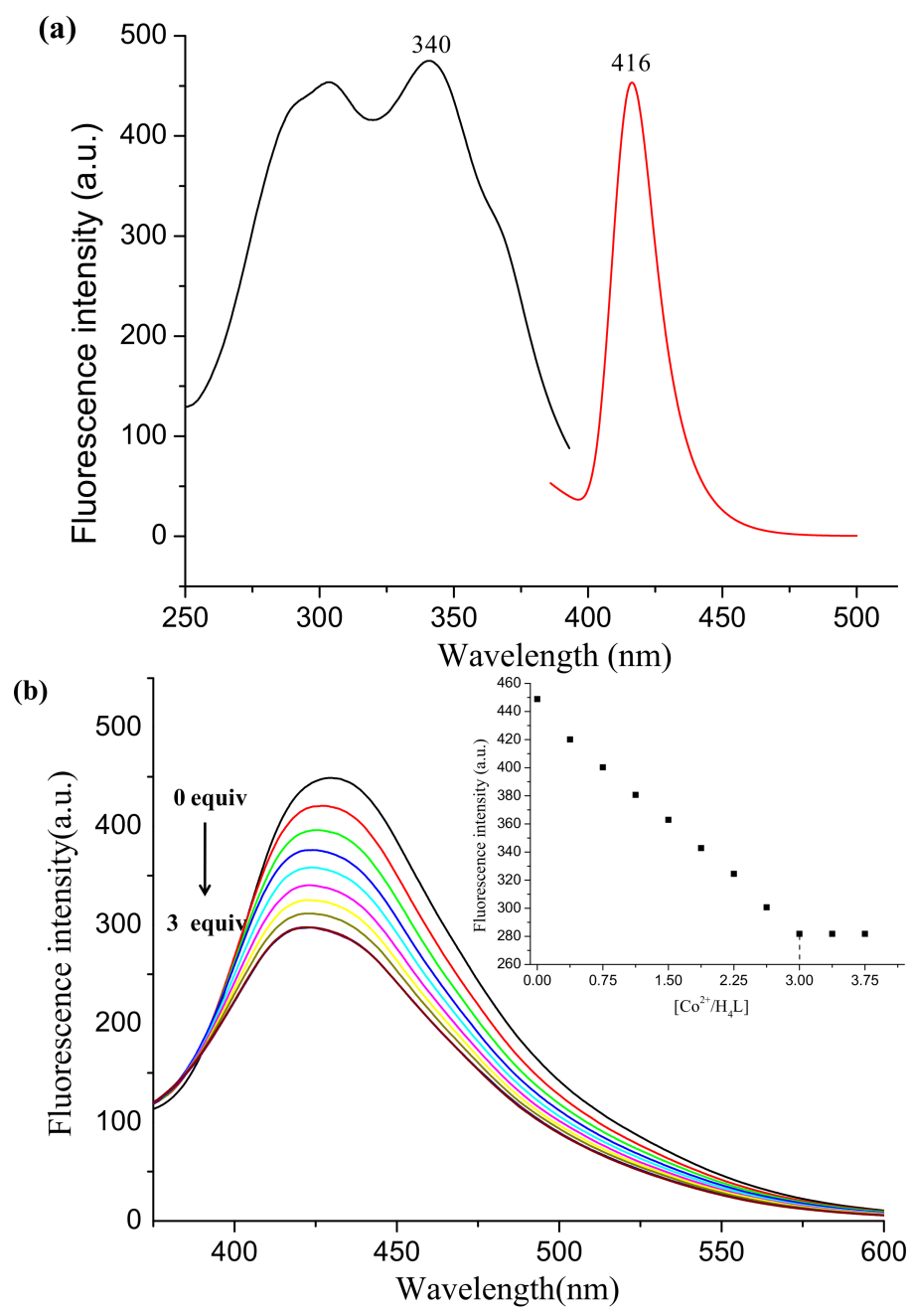

Figure 9. (a) The excitation and emission spectra of the Co(II) complex. (b) fluorescence emission spectrum changes of $\mathrm{H}_{4} \mathrm{~L}$ in methanol solution by the addition of $\mathrm{Co}(\mathrm{II})$ ions.

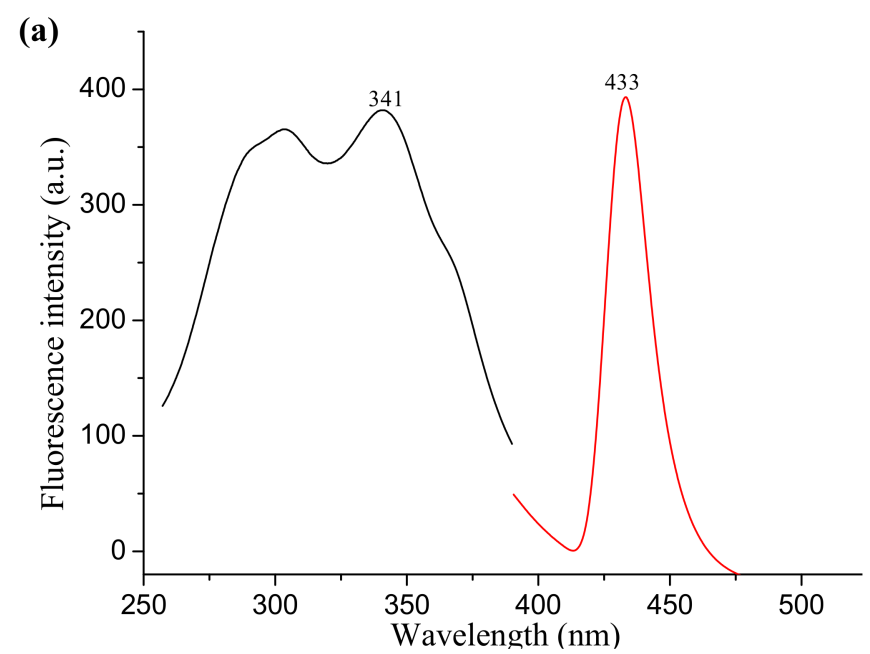

Figure 10. Cont. 


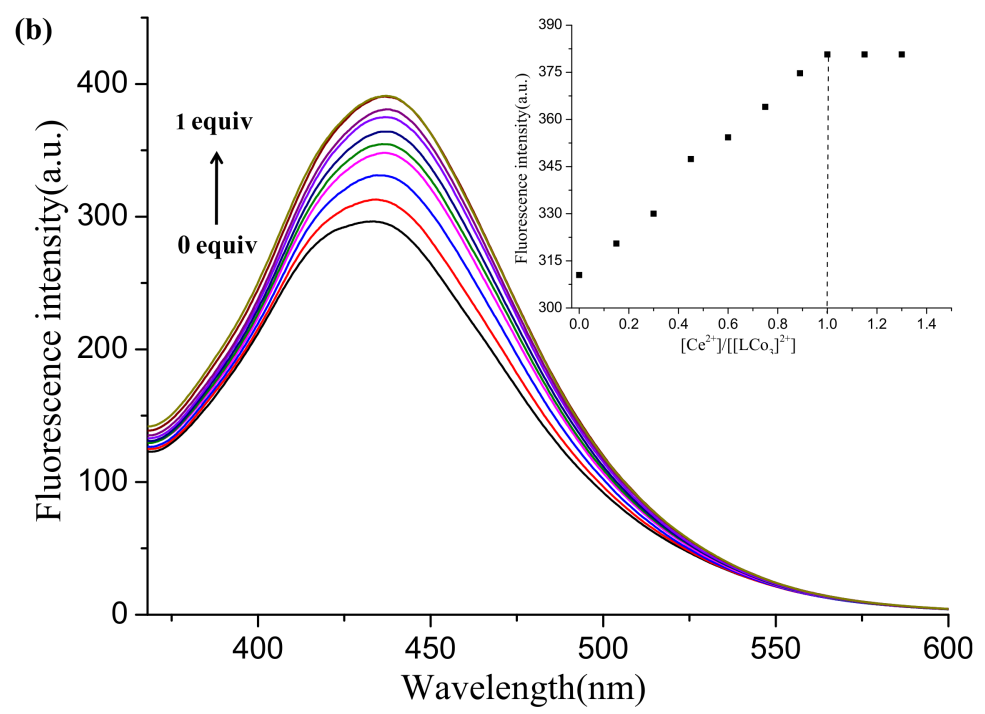

Figure 10. (a) The excitation and emission spectra of the Co(II)-Ce(III) complex; (b) Fluorescence spectrum changes of $\mathrm{Co}(\mathrm{II})$ complex in methanol solution by the addition of $\mathrm{Ce}(\mathrm{III})$ ions.

\section{Experimental Section}

\subsection{Materials and Methods}

2-Hydroxy-3-methoxybenzaldehyde (99\%), methyltrioctylammonium chloride (90\%), pyridinium chlorochromate (98\%) and boron tribromide (99.9\%) were bought from Alfa Aesar (New York, NY, USA) $33 \mathrm{wt} \%$ hydrobromic acid solution in acetic acid was purchased from J\&K Scientific Ltd. (Beijing, China). The other general reagents and solvents in this work were used directly without further purification in the preparation of the free ligand and its complex. Elemental analyses $(\mathrm{C}, \mathrm{H}$ and $\mathrm{N})$ were carried out using a VarioEL V3.00 automatic elemental analysis instrument (Elementar, Berlin, Germany).Elemental analyses for metals were performed on an ER/S.WP-1 ICP atomic emission spectrometer (IRIS, Elementar, Berlin, Germany).Melting points were measured using a microscopic melting point apparatus made by Beijing Taike Instrument Limited Company(Beijing, China) and were uncorrected. Infrared spectra were recorded between 500 and $4000 \mathrm{~cm}^{-1}$ on a VERTEX 70FT-IR spectrophotometer (Bruker, Billerica, MA, USA)for samples prepared as KBr pellets. UV-Vis spectra in the $250-550 \mathrm{~nm}$ range were recorded by a $\mathrm{U}-3900 \mathrm{H}$ spectrometer (Hitachi, Shimadzu, Tokyo, Japan). Fluorescence spectra were taken on a Hitachi F-7000 fluorescence photometer.(Hitachi, Tokyo, Japan). ${ }^{1} \mathrm{H}-\mathrm{NMR}$ spectra were determined with a German Bruker AVANCE DRX-400 spectrometer (Bruker AVANCE, Billerica, MA, USA). X-ray single crystal structure determination was carried out

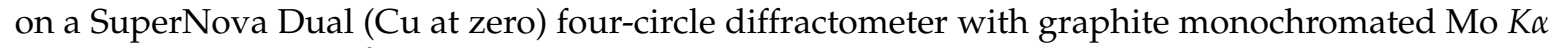
radiation $(\lambda=0.71073 \AA$ ) at 293.66(10) K (Bruker, Billerica, MA, USA). Reflection data were corrected for Lorentzian and polarization effects and for absorption using the multi-scan method.

\subsection{Synthesis of the Bi(salamo)-Type Ligand $H_{4} L$}

The synthesis of the bi(salamo)-type ligand $\mathrm{H}_{4} \mathrm{~L}$ is shown in Scheme 1. 2,3-Dihydroxynaphthalene1,4-dicarbaldehyde was prepared according to a literature procedure [77]. 2,3-Dihydroxynaphthalene-1,4dicarbaldehyde and 2-[O-(1-ethyloxyamide)]oxime-6-methoxy- phenol were synthesized according to an analogous method [78,79]. A mixed solution of 2,3-dihydroxynaphthalene-1,4-dicarbaldehyde $(108.1 \mathrm{mg}, 0.50 \mathrm{mmol})$ in ethanol $(10 \mathrm{~mL})$ and 2-[O-(1-ethyloxyamide)]oxime-6-methoxyphenol $(226.1 \mathrm{mg}, 1.00 \mathrm{mmol})$ in ethanol $(10 \mathrm{~mL})$ was heated at $55{ }^{\circ} \mathrm{C}$ for $4 \mathrm{~h}$. After cooling to room temperature, the obtained yellow precipitate was filtered off and dried under vacuum to obtain light yellow crystalline solid. Yield: $59 \%$. m.p. $170-171^{\circ} \mathrm{C}$. Anal. Calcd. (\%) for $\mathrm{C}_{32} \mathrm{H}_{32} \mathrm{~N}_{4} \mathrm{O}_{10}$ (632.42): C, 
60.75; H, 5.10; N, 8.86. Found (\%): C, 60.93; H, 5.23; N, 8.74. ${ }^{1} \mathrm{H}-\mathrm{NMR}\left(400 \mathrm{MHz}, \mathrm{CDCl}_{3}\right)$ : no instrument listed in $3.1 \delta(\mathrm{ppm})=11.03(\mathrm{~s}, 2 \mathrm{H}), 9.82(\mathrm{~s}, 2 \mathrm{H}), 9.14(\mathrm{~s}, 2 \mathrm{H}), 8.29(\mathrm{~s}, 2 \mathrm{H}), 7.97(\mathrm{q}, J=3.2 \mathrm{~Hz}, 2 \mathrm{H}), 7.41$ $(\mathrm{q}, J=6.0,2.9 \mathrm{~Hz}, 2 \mathrm{H}), 7.06-6.68(\mathrm{~m}, 6 \mathrm{H}), 4.58(\mathrm{t}, 8 \mathrm{H}), 3.89(\mathrm{~s}, 6 \mathrm{H})$. UV-Vis [in methanol/chloroform $(1: 1)], \lambda_{\max }(\mathrm{nm})\left[2.5 \times 10^{-5} \mathrm{M}\right]: 342,360,375$.
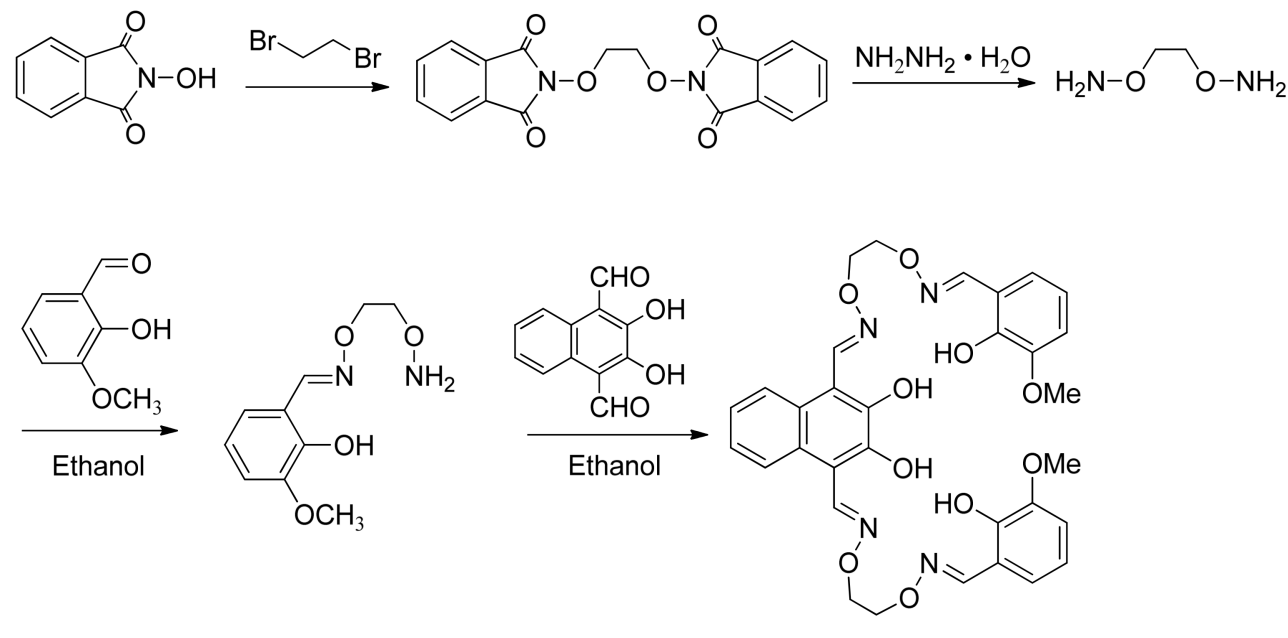

$\mathrm{H}_{4} \mathrm{~L}$

Scheme 1. Synthetic route to the bi(salamo)-type ligand $\mathrm{H}_{4} \mathrm{~L}$.

\subsection{Synthesis of the Heterotrinuclear Co(II)-Ce(III) Complex}

A mixed solution of $\mathrm{Co}(\mathrm{OAc})_{2} \cdot 4 \mathrm{H}_{2} \mathrm{O}(4.98 \mathrm{mg}, 0.02 \mathrm{mmol})$ in ethanol $(2 \mathrm{~mL})$ and $\mathrm{Ce}(\mathrm{OAc})_{3} \cdot \mathrm{H}_{2} \mathrm{O}$ $(3.35 \mathrm{mg}, 0.01 \mathrm{mmol}))$ in water/methanol $(1: 1,2 \mathrm{~mL})$ was added to a solution of the ligand $\mathrm{H}_{4} \mathrm{~L}(6.32 \mathrm{mg}$, $0.01 \mathrm{mmol})$ in dichloromethane $(2 \mathrm{~mL})$. Then the resulting mixed solution immediately turned yellow and was stirred at room temperature for $30 \mathrm{~min}$. The mixture was filtered and the filtrate was allowed to stand at room temperature for approximately four weeks, giving colorless prismatic single crystals suitable for X-ray crystallographic analysis. Yield: $37 \%$. Anal. Calcd. (\%) for $\mathrm{C}_{42} \mathrm{H}_{50} \mathrm{ClCo}_{2} \mathrm{CeN}_{4} \mathrm{O}_{18.50}$ (1200.29): C, 42.03; H, 4.20; N, 4.67; Co, 9.82; Ce, 11.67. Found (\%): C, 42.25; H, 4.47; N, 4.51; Co, 9.64; $\mathrm{Ce}, 11.49$. UV-Vis [in methanol $\left./ \mathrm{H}_{2} \mathrm{O}(10: 1 v / v)\right], \lambda_{\max }(\mathrm{nm})\left[1.0 \times 10^{-3} \mathrm{M}\right]: 346,364,380$.

\subsection{Crystal Structure Determination and Refinement}

The structure was solved by direct methods (SHELX-2014) and refined anisotropically using full-matrix least-squares methods on $F^{2}$ with the SHELX-2014 program package. Lp and semi-empirical absorption corrections by SADABS were applied to the intensity data. The non-hydrogen atoms were refined anisotropically except for the solvent molecules of the crystal of the Co(II)-Ce(III) complex. All hydrogen atoms were added in calculated positions. Supplementary crystallographic data for this paper have been deposited at Cambridge Crystallographic Data Centre (1814394) and can be obtained free of charge via www.ccdc.cam.ac.uk/conts/retrieving.html.

\section{Conclusions}

The synthesis, structural characterization, and fluorescence properties of the bis(salamo)-type ligand $\mathrm{H}_{4} \mathrm{~L}$ and its corresponding heterotrinuclear $\mathrm{Co}(\mathrm{II})-\mathrm{Ce}(\mathrm{III})$ complex were described. The X-ray crystal structure revealed that two $\mathrm{Co}(\mathrm{II})$ atoms are located in the $\mathrm{N}_{2} \mathrm{O}_{2}$ coordination environment and are both hexacoordinated with slightly distorted octahedral geometries. Simultaneously, the $\mathrm{O}_{6}$ cavity of the completely deprotonated $(\mathrm{L})^{4-}$ unit is occupied by the $\mathrm{Ce}(\mathrm{III})$ atom which is nine-coordinated with a single square antiprismatic geometry. The UV-Vis titration experiments revealed the ratio of the heterotrinuclear Co(II)-Ce(III) complex is 1:2:1 (ligand/Co(II)/Ce(III)). Ethanol as a coordinating solvent participates in the coordination in the Co(II)-Ce(III) complex. 
The different peak wavelength variation of the heterotrinuclear complex clearly showed the success of transformation from homotrinuclear to heteronuclear complex, which could be used in host-guest systems. Furthermore, the Co(II)-Ce(III) complex showed weak photoluminescence and exhibiting a hypsochromic-shift.

Acknowledgments: This work was supported by the National Natural Science Foundation of China (21761018) and the Program for Excellent Team of Scientific Research in Lanzhou Jiaotong University (201706), which is gratefully acknowledged.

Author Contributions: L.-M.P. and W.-K.D. supervised the project and contributed materials/reagents/analysis tools; L.-Z.L., H.Z. and H.-T.L. performed the experiments; W.-K.D., Q.Z. wrote the manuscript.

Conflicts of Interest: The authors declare no conflict of interest.

\section{References}

1. Chai, L.Q.; Li, Y.X.; Chen, L.C.; Zhang, J.Y.; Huang, J.J. Synthesis, X-ray structure, spectroscopic, electrochemical properties and DFT calculation of a bridged dinuclear copper(II) complex. Inorg. Chem. Acta 2016, 444, 193-201. [CrossRef]

2. Ma, X.; Jiao, J.M.; Yang, J.; Huang, X.B.; Cheng, Y.X.; Zhu, C.J. Large stokes shift chiral polymers containing $(R, R)$-salen-based binuclear boron complex: Synthesis, characterization, and fluorescence properties. Polyhedron 2012, 53, 3894-3899. [CrossRef]

3. Zhao, L.; Wang, L.; Sun, Y.X.; Dong, W.K.; Tang, X.L.; Gao, X.H. A supramolecular copper(II) complex bearing salen-type bisoxime ligand: Synthesis, structural characterization and thermal property. Synth. React. Inorg. Met-Org. Nano-Met. Chem. 2012, 42, 1303-1308. [CrossRef]

4. Subramaniam, P.; Anbarasan, S.; Devi, S.S.; Ramdass, A. Modulation of catalytic activity by ligand oxides in the sulfoxidation of phenylmercaptoacetic acids by oxo(salen)chromium(V) complexes. Polyhedron 2016, 119, 14-22. [CrossRef]

5. Sun, Y.X.; Zhang, S.T.; Ren, Z.L.; Dong, X.Y.; Wang, L. Synthesis, characterization, and crystal structure of a new supramolecular $\mathrm{Cd}^{\mathrm{II}}$ complex with halogen-substituted salen-type bisoxime. Synth. React. Inorg. Met.-Org. Nano-Met. Chem. 2013, 43, 995-1000. [CrossRef]

6. Shu, Y.B.; Liu, W.S. Luminescent chiral Eu(III) complexes with enantiopure bis(1H-pyridin-2-one)salen ligands. Polyhedron 2015, 102, 293-296. [CrossRef]

7. Sun, Y.X.; Gao, X.H. Synthesis, characterization, and crystal structure of a new Cu ${ }^{\mathrm{II}}$ complex with salen-type ligand. Synth. React. Inorg. Met.-Org. Nano-Met. Chem. 2011, 41, 973-978. [CrossRef]

8. Sun, Y.X.; Xu, L.; Zhao, T.H.; Liu, S.H.; Liu, G.H.; Dong, X.T. Synthesis and crystal structure of a 3D supramolecular copper(II) complex with 1-(3-\{[(E)-3-bromo-5-chloro-2-hydroxybenzylidene ]amino\}phenyl) ethanone oxime. Synth. React. Inorg. Met.-Org. Nano-Met. Chem 2013, 43, 509-513. [CrossRef]

9. Song, X.Q.; Liu, P.P.; Wang, C.Y.; Liu, Y.A.; Liu, W.S.; Zhang, M. Three sandwich-type zinc(II)-lanthanide(III) clusters: Structures, luminescence and magnetic properties. RSC Adv. 2017, 7, 22692-22698. [CrossRef]

10. Liu, P.P.; Sheng, L.; Song, X.Q.; Xu, W.Y.; Liu, Y.A. Synthesis, structure and magnetic properties of a new one dimensional manganese coordination polymer constructed by a new asymmetrical ligand. Inorg. Chim. Acta 2015, 434, 252-257. [CrossRef]

11. Song, X.Q.; Liu, P.P.; Xiao, Z.R.; Li, X.; Liu, Y.A. Four polynuclear complexes based on a versatile salicylamide salen-like ligand: Synthesis, structural variations and magnetic properties. Inorg. Chim. Acta 2015, 438, 232-244. [CrossRef]

12. Liu, Y.A.; Wang, C.Y.; Zhang, M.; Song, X.Q. Structures and magnetic properties of cyclic heterometallic tetranuclear clusters. Polyhedron 2017, 127, 278-286. [CrossRef]

13. Zhou, J.J.; Song, X.Q.; Liu, Y.A.; Wang, X.L. Substituent-tuned structure and luminescence sensitizing towards $\mathrm{Al}^{3+}$ based on phenoxy bridged dinuclear Eu ${ }^{\mathrm{III}}$ complexes. RSC Adv. 2017, 7, 25549-25559. [CrossRef]

14. Dong, W.K.; Ma, J.C.; Zhu, L.C.; Zhang, Y. Nine self-assembled nickel(II)-lanthanide(III) heterometallic complexes constructed from a Salamo-type bisoxime and bearing a N- or O-donor auxiliary ligand: Syntheses, structures and magnetic properties. New J. Chem. 2016, 40, 6998-7010. [CrossRef] 
15. Chin, T.K.; Endud, S.; Jamil, S.; Budagumpi, S.; Lintang, H.O. Oxidative dimerization of o-aminophenol by heterogeneous mesoporous material modified with biomimetic salen-type copper(II) complex. Catal. Lett. 2013, 143, 282-288. [CrossRef]

16. Li, X.Y.; Chen, L.; Gao, L.; Zhang, Y.; Akogun, S.F.; Dong, W.K. Syntheses, crystal structures and catalytic activities of two solvent-induced homotrinuclear Co(II) complexes with a naphthalenediol-based bis(salamo)-type tetraoxime ligand. RSC Adv. 2017, 7, 35905-35916. [CrossRef]

17. Ömer, S.; Ümmühan, Ö.Ö.; Nurgul, S.; Burcu, A.; Musa, S.; Tuncay, T.; Zeynel, S. A highly selective and sensitive chemosensor derived coumarin-thiazole for colorimetric and fluorimetric detection of $\mathrm{CN}^{-}$ion in DMSO and aqueous solution: Synthesis, sensing ability, $\mathrm{Pd}(\mathrm{II}) / \mathrm{Pt}(\mathrm{II})$ complexes and theoretical studies. Tetrahedron 2016, 72, 5843-5852.

18. Wang, L.; Li, X.Y.; Zhao, Q.; Li, L.H.; Dong, W.K. Fluorescence properties of heterotrinuclear Zn(II)-M(II) $(\mathrm{M}=\mathrm{Ca}$, Sr and Ba) bis(salamo)-type complexes. RSC Adv. 2017, 7, 48730-48737. [CrossRef]

19. Wu, H.L.; Bai, Y.C.; Zhang, Y.H.; Li, Z.; Wu, M.C.; Chen, C.Y.; Zhang, J.W. Synthesis, crystal structure, antioxidation and DNA-binding properties of a dinuclear copper(II) complex with bis( $N$-salicylidene)-3-oxapentane-1,5-diamine. J. Coord. Chem. 2014, 67, 3054-3066. [CrossRef]

20. Chen, C.Y.; Zhang, J.W.; Zhang, Y.H.; Yang, Z.H.; Wu, H.L.; Pan, G.L.; Bai, Y.C. Gadolinium(III) and dysprosium(III) complexes with a Schiff base bis( $N$-salicylidene)-3-oxapentane-1,5-diamine: Synthesis, characterization, antioxidation, and DNA-binding studies. J. Coord. Chem. 2015, 68, 1054-1071. [CrossRef]

21. Wu, H.L.; Bai, Y.H.; Zhang, Y.H.; Pan, G.L.; Kong, J.; Shi, F.R.; Wang, X.L. Two lanthanide(III) complexes based on the Schiff base $N, N^{\prime}$-Bis(salicylidene)-1,5-diamino-3-oxapentane: Synthesis, characterization, DNA-binding properties, and antioxidation. Z. Anorg. Allg. Chem. 2014, 640, 2062-2071. [CrossRef]

22. Wu, H.L.; Pan, G.L.; Wang, H.; Wang, X.L.; Bai, Y.C.; Zhang, Y.H. Study on synthesis, crystal structure, antioxidant and DNA-binding of mono-, di- and poly-nuclear lanthanides complexes with bis(N-salicylidene)-3-oxapentane-1,5-diamine. J. Photochem. Photobiol. B Biol. 2014, 135, 33-43. [CrossRef] [PubMed]

23. Wu, H.L.; Pan, G.L.; Bai, Y.C.; Wang, H.; Kong, J.; Shi, F.; Zhang, Y.H.; Wang, X.L. Preparation, structure, DNA-binding properties, and antioxidant activities of a homodinuclear erbium(III) complex with a pentadentate Schiff base ligand. J. Chem. Res. 2014, 38, 211-217. [CrossRef]

24. Wu, H.L.; Wang, H.; Wang, X.L.; Pan, G.L.; Shi, F.R.; Zhang, Y.H.; Bai, Y.C.; Kong, J. V-shaped ligand bis(2-benzimidazolylmethyl)amine containing three copper(II) ternary complexes: Synthesis, structure, DNA-binding properties and antioxidant activity. New J. Chem. 2014, 38, 1052-1061. [CrossRef]

25. Mao, S.S.; Shen, K.S.; Shi, X.K.; Wu, H.L.; Han, X.T.; Li, C.; Huang, G.Z. Synthesis, crystal structure and biological activity of two binuclear $\operatorname{Ag}(\mathrm{I})$ complexes with bis-benzimidazole thioether ligands. Inorg. Chim. Acta 2018, 471, 82-90. [CrossRef]

26. Wu, H.L.; Pan, G.L.; Bai, Y.C.; Wang, H.; Kong, J.; Shi, F.R.; Zhang, Y.H.; Wang, X.L. Synthesis, structure, antioxidation, and DNA-binding studies of a binuclear ytterbium(III) complex with bis(N-salicylidene)-3-oxapentane-1,5-diamine. Res. Chem. Intermed. 2015, 41, 3375-3388. [CrossRef]

27. Wang, F.; Xu, Y.L.; Aderinto, S.O.; Peng, H.P.; Zhang, H.; Wu, H.L. A new highly effective fluorescent probe for $\mathrm{Al}^{3+}$ ions and its application in practical samples. J. Photochem. Photobiol. A 2017, 332, 273-282. [CrossRef]

28. Wu, H.L.; Bai, Y.; Yuan, J.K.; Wang, H.; Pan, G.L.; Fan, X.Y.; Kong, J. A zinc(II) complex with tris(2-(-methyl)benzimidazlylmethyl)amine and salicylate: Synthesis, crystal structure, and DNA-binding. J. Coord. Chem. 2012, 65, 2839-2851. [CrossRef]

29. Chai, L.Q.; Wang, G.; Sun, Y.X.; Dong, W.K.; Zhao, L.; Gao, X.H. Synthesis, crystal structure, and fluorescence of an unexpected dialkoxo-bridged dinuclear copper(II) complex with bis(salen)-type tetraoxime. J. Coord. Chem. 2012, 65, 1621-1631. [CrossRef]

30. Chai, L.Q.; Huang, J.J.; Zhang, H.S.; Zhang, Y.L.; Zhang, J.Y.; Li, Y.X. An unexpected cobalt(III) complex containing a Schiff base ligand: Synthesis, crystal structure, spectroscopic behavior, electrochemical property and SOD-like activity. Spectrochim. Acta Part A 2014, 131, 526-531. [CrossRef] [PubMed]

31. Chai, L.Q.; Liu, G.; Zhang, J.Y.; Huang, J.J.; Tong, J.F. Synthesis, crystal structure, fluorescence, electrochemical property, and SOD-like activity of an unexpected nickel(II) complex with a quinazoline-type ligand. J. Coord. Chem. 2013, 66, 3926-3938. [CrossRef] 
32. Chai, L.Q.; Zhang, H.S.; Huang, J.J.; Zhang, Y.L. An unexpected Schiff base-type Ni(II) complex: Synthesis, crystal structures, fluorescence, electrochemical property and SOD-like activities. Spectrochim. Acta Part A 2015, 137, 661-669. [CrossRef] [PubMed]

33. Chai, L.Q.; Tang, L.J.; Chen, L.C.; Huang, J.J. Structural, spectral, electrochemical and DFT studies of two mononuclear manganese(II) and zinc(II) complexes. Polyhedron 2017, 122, 228-240. [CrossRef]

34. Chai, L.Q.; Zhang, K.Y.; Tang, L.J.; Zhang, J.Y.; Zhang, H.S. Two mono- and dinuclear Ni(II) complexes constructed from quinazoline-type ligands: Synthesis, X-ray structures, spectroscopic, electrochemical, thermal, and antimicrobial studies. Polyhedron 2017, 130, 100-107. [CrossRef]

35. Chen, L.; Dong, W.K.; Zhang, H.; Zhang, Y.; Sun, Y.X. Structural variation and luminescence properties of triand dinuclear $\mathrm{Cu}^{\mathrm{II}}$ and $\mathrm{Zn}^{\mathrm{II}}$ complexes constructed from a naphthalenediol-based bis(Salamo)-type ligand. Cryst. Growth Des. 2017, 17, 3636-3648. [CrossRef]

36. Dong, X.Y.; Li, X.Y.; Liu, L.Z.; Zhang, H.; Ding, Y.J.; Dong, W.K. Tri- and hexanuclear heterometallic $\mathrm{Ni}(\mathrm{II})-\mathrm{M}(\mathrm{II})(\mathrm{M}=\mathrm{Ca}, \mathrm{Sr}$ and Ba) bis(salamo)-type complexes: Synthesis, structure and fluorescence properties. RSC Adv. 2017, 7, 48394-48403. [CrossRef]

37. Song, X.Q.; Peng, Y.J.; Chen, G.Q.; Wang, X.R.; Liu, P.P.; Xu, W.Y. Substituted group-directed assembly of $\mathrm{Zn}(\mathrm{II})$ coordination complexes based on two new structural related pyrazolone based Salen ligands: Syntheses, structures and fluorescence properties. Inorg. Chim. Acta 2015, 427, 13-21. [CrossRef]

38. Wang, P.; Zhao, L. An infinite 2D supramolecular cobalt(II) complex based on an asymmetric salamo-type ligand: Synthesis, crystal structure, and spectral properties. Synth. React. Inorg. Met.-Org. Nano-Met. Chem. 2016, 46, 1095-1101. [CrossRef]

39. Dong, X.Y.; Akogun, S.F.; Zhou, W.M.; Dong, W.K. Tetranuclear Zn(II) complex based on an asymmetrical salamo-type chelating ligand: Synthesis, structural characterization, and fluorescence property. J. Chin. Chem. Soc. 2017, 64, 412-419. [CrossRef]

40. Tao, C.H.; Ma, J.C.; Zhu, L.C.; Zhang, Y.; Dong, W.K. Heterobimetallic 3d-4f Zn(II)-Ln(III) (Ln = Sm, Eu, $\mathrm{Tb}$ and $\mathrm{Dy}$ ) complexes with a $\mathrm{N}_{2} \mathrm{O}_{4}$ bisoxime chelate ligand and a simple auxiliary ligand Py: Syntheses, structures and luminescence properties. Polyhedron 2017, 128, 38-45. [CrossRef]

41. Dong, Y.J.; Dong, X.Y.; Dong, W.K.; Zhang, Y.; Zhang, L.S. Three asymmetric salamo-type copper(II) and cobalt(II) complexes: Syntheses, structures, fluorescent properties. Polyhedron 2017, 123, 305-315. [CrossRef]

42. Dong, W.K.; Ma, J.C.; Dong, Y.J.; Zhao, L.; Zhu, L.C.; Sun, Y.X.; Zhang, Y. Two hetero-trinuclear Zn(II)-M(II) $(\mathrm{M}=\mathrm{Sr}, \mathrm{Ba})$ complexes based on metallohost of mononuclear $\mathrm{Zn}(\mathrm{II})$ complex: Syntheses, structures and fluorescence properties. J. Coord. Chem. 2016, 69, 3231-3241. [CrossRef]

43. Wu, H.L.; Wang, C.P.; Wang, F.; Peng, H.P.; Zhang, H.; Bai, Y.C. A new manganese(III) complex from bis(5-methylsalicylaldehyde)-3-oxapentane-1,5-diamine: Synthesis, characterization, antioxidant activity and luminescence. J. Chin. Chem. Soc. 2015, 62, 1028-1034. [CrossRef]

44. Wang, L.; Ma, J.C.; Dong, W.K.; Zhu, L.C.; Zhang, Y. A novel Self-assembled nickel(II)-cerium(III) heterotetranuclear dimer constructed from $\mathrm{N}_{2} \mathrm{O}_{2}$-type bisoxime and terephthalic acid: Synthesis, structure and photophysical properties. Z. Anorg. Allg. Chem. 2016, 642, 834-839. [CrossRef]

45. Dong, Y.J.; Li, X.L.; Zhang, Y.; Dong, W.K. A highly selective visual and fluorescent sensor for $\mathrm{Pb}^{2+}$ and $\mathrm{Zn}^{2+}$ and crystal structure of $\mathrm{Cu}^{2+}$ complex based-on a novel single-armed salamotype bisoxime. Supramol. Chem. 2017, 29, 518-527. [CrossRef]

46. Liu, P.P.; Wang, C.Y.; Zhang, M.; Song, X.Q. Pentanuclear sandwich-type Zn ${ }^{\mathrm{II}}$-Ln ${ }^{\mathrm{III}}$ clusters based on a new salen-like salicylamide ligand: Structure, near-infrared emission and magnetic properties. Polyhedron 2017, 129, 133-140. [CrossRef]

47. Li, G.; Hao, J.; Liu, L.Z.; Zhou, W.M.; Dong, W.K. Syntheses, crystal structures and thermal behaviors of two supramolecular salamo-type cobalt(II) and zinc(II) complexes. Crystals 2017, 7, 217.

48. Wang, B.J.; Dong, W.K.; Zhang, Y.; Akogun, S.F. A novel relay-sensor for highly sensitive and selective detection of $\mathrm{Zn}^{2+} / \mathrm{Pic}^{-}$and fluorescence on/off switch response of $\mathrm{H}^{+} / \mathrm{OH}^{-}$. Sens. Actuators B Chem. 2017, 247, 254-264. [CrossRef]

49. Dong, W.K.; Li, G.; Wang, Z.K.; Dong, X.Y. A novel trinuclear cobalt(II) complex derived from an asymmetric salamo-type $\mathrm{N}_{2} \mathrm{O}_{3}$ bisoxime chelate ligand: Synthesis, structure and optical properties. Spectrochim. Acta Part A 2014, 133, 340-347. [CrossRef] [PubMed]

50. Dong, X.Y.; Gao, L.; Wang, F.; Zhang, Y.; Dong, W.K. Tri- and mono-nuclear zinc(II) complexes based on halfand mono-salamo chelating ligands. Crystals 2017, 7, 267. [CrossRef] 
51. Yu, B.; Li, C.Y.; Sun, Y.X.; Jia, H.R.; Guo, J.Q.; Li, J. A new azine derivative colorimetric and fluorescent dual-channel probe for cyanide detection. Spectrochim. Acta Part A 2017, 184, 249-254. [CrossRef] [PubMed]

52. Dong, W.K.; Lan, P.F.; Zhou, W.M.; Zhang, Y. Salamo-type trinuclear and tetranuclear cobalt (II) complexes based on a new asymmetry salamo-type ligand: Syntheses, crystal structures, and fluorescence. J. Coord. Chem. 2016, 69, 1-22. [CrossRef]

53. Xu, L.; Zhu, L.C.; Ma, J.C.; Zhang, Y.; Zhang, J.; Dong, W.K. Syntheses, structures and spectral properties of mononuclear $\mathrm{Cu}^{\mathrm{II}}$ and dimeric $\mathrm{Zn}^{\mathrm{II}}$ complexes based on an asymmetric Salamo-type $\mathrm{N}_{2} \mathrm{O}_{2}$ ligand. Z. Anorg. Allg. Chem. 2015, 641, 2520-2524. [CrossRef]

54. Wang, F.; Gao, L.; Zhao, Q.; Zhang, Y.; Dong, W.K.; Ding, Y.J. A highly selective fluorescent chemosensor for $\mathrm{CN}^{-}$based on a novel bis(salamo)-type tetraoxime ligand. Spectrochim. Acta Part A 2018, 190, 111-115. [CrossRef] [PubMed]

55. Gao, L.; Wang, F.; Zhao, Q.; Zhang, Y.; Dong, W.K. Mononuclear Zn(II) and trinuclear Ni(II) complexes derived from a coumarin-containing $\mathrm{N}_{2} \mathrm{O}_{2}$ ligand: Syntheses, crystal structures and fluorescence properties. Polyhedron 2018, 139, 7-16. [CrossRef]

56. Dong, W.K.; Du, W.; Zhang, X.Y.; Li, G.; Dong, X.Y. Synthesis, crystal structure and spectral properties of a supramolecular trinuclear nickel(II) complex with 5-methoxy-4'-bromo2,2'-[ethylenedioxybis(nitrilomethylidyne)]diphenol. Spectrochim. Acta Part A 2014, 132, 588-593. [CrossRef] [PubMed]

57. Dong, W.K.; Zheng, S.S.; Zhang, J.T.; Zhang, Y.; Sun, Y.X. Luminescent properties of heterotrinuclear 3d-4f complexes constructed from a naphthalenediol-based acyclic bis(salamo)-type ligand. Spectrochim. Acta Part A 2017, 184, 141-150. [CrossRef] [PubMed]

58. Dong, Y.J.; Ma, J.C.; Zhu, L.C.; Dong, W.K.; Zhang, Y. Four 3d-4f heteromultinuclear zinc(II)-lanthanide(III) complexes constructed from a distinct hexadentate $\mathrm{N}_{2} \mathrm{O}_{2}$-type ligand: Syntheses, structures and luminescence properties. J. Coord. Chem. 2017, 70, 103-115. [CrossRef]

59. Ma, J.C.; Dong, X.Y.; Dong, W.K.; Zhang, Y.; Zhu, L.C.; Zhang, J.T. An unexpected dinuclear Cu(II) complex with a bis(Salamo) chelating ligand: Synthesis, crystal structure, and photophysical properties. J. Coord. Chem. 2016, 69, 149-159. [CrossRef]

60. Dong, W.K.; Ma, J.C.; Dong, Y.J.; Zhu, L.C.; Zhang, Y. Di- and tetranuclear heterometallic 3d-4f cobalt(II)-lanthanide(III) complexes derived from a hexadentate bisoxime: Syntheses, structures and magnetic properties. Polyhedron 2016, 115, 228-235. [CrossRef]

61. Dong, W.K.; Ma, J.C.; Zhu, L.C.; Zhang, Y. Self-assembled zinc(II)-lanthanide(III) heteromultinuclear complexes constructed from 3-MeOsalamo ligand: Syntheses, structures and luminescent properties. Cryst. Growth Des. 2016, 16, 6903-6914. [CrossRef]

62. Zhang, H.; Dong, W.K.; Zhang, Y.; Akogun, S.F. Naphthalenediol-based bis(Salamo)-type homo- and heterotrinuclear cobalt(II) complexes: Syntheses, structures and magnetic properties. Polyhedron 2017, 133, 279-293. [CrossRef]

63. Li, L.H.; Dong, W.K.; Zhang, Y.; Akogun, S.F.; Xu, L. Syntheses, structures and catecholase activities of homo- and hetero-trinuclear cobalt(II) complexes constructed from an acyclic naphthalenediolbased bis(Salamo)-type ligand. Appl. Organomet. Chem. 2017, 31, e3818. [CrossRef]

64. Wang, L.; Hao, J.; Zhai, L.X.; Zhang, Y.; Dong, W.K. Synthesis, crystal structure, luminescence, electrochemical and antimicrobial properties of bis(salamo)-based Co(II) complex. Crystals 2017, 7, 277. [CrossRef]

65. Li, X.Y.; Kang, Q.P.; Liu, L.Z.; Ma, J.C.; Dong, W.K. Trinuclear Co(II) and mononuclear Ni(II) Salamo-type bisoxime coordination compounds. Crystals 2018, 8, 43. [CrossRef]

66. Peng, Y.D.; Li, X.Y.; Kang, Q.P.; An, G.X.; Zhang, Y.; Dong, W.K. Synthesis and fluorescence properties of asymmetrical Salamo-type tetranuclear zinc(II) complex. Crystals 2018, 8, 107. [CrossRef]

67. Gao, L.; Liu, C.; Wang, F.; Dong, W.K. Tetra-, penta- and hexa-coordinated transition metal complexes constructed from coumarin-containing $\mathrm{N}_{2} \mathrm{O}_{2}$ ligand. Crystals 2018, 8, 77. [CrossRef]

68. Sun, Y.X.; Li, C.Y.; Yang, C.J.; Zhao, Y.Y.; Guo, J.Q.; Yu, B. Two Cu(II) complexes with Schiff base ligands: Syntheses, crystal structures, spectroscopic properties and substituent effect. Chin. J. Inorg. Chem. 2016, 32, 327-335.

69. Yu, B.; Sun, Y.X.; Yang, C.J.; Guo, J.Q.; Li, J. Synthesis and crystal structures of an unexpected tetranuclear zinc(II) complex and a benzoquinone compound derived from $\mathrm{Zn}^{\mathrm{II}}$ - and $\mathrm{Cd}^{\mathrm{II}}$-promoted reactivity of Schiff base ligands. Z. Anorg. Allg. Chem. 2017, 643, 689-698. [CrossRef] 
70. Sun, Y.X.; Lu, R.E.; Li, X.R.; Zhao, Y.Y.; Li, C.Y. A Schiff base ligand containing oxime group and its Cu(II) complex: Syntheses and supramolecular structures. Chin. J. Inorg. Chem. 2015, 31, 1055-1062.

71. Guo, J.Q.; Sun, Y.X.; Yu, B.; Li, J.; Jia, H.R. Syntheses, crystal structures and spectroscopic properties of copper(II) and nickel(II) complexes with oxime-type Schiff base ligands. Chin. J. Inorg. Chem. 2017, 33, 1481-1488.

72. Xu, Y.L.; Mao, S.S.; Shen, K.S.; Shi, X.K.; Wu, H.L.; Tang, X. Different structures of two Cu(I) complexes constructed by bridging 2,2-(1,4-butanediyl)bis-1,3-benzoxazole ligand: Syntheses, structures and properties. Inorg. Chim. Acta 2018, 471, 17-22. [CrossRef]

73. Sun, Y.X.; Zhao, Y.Y.; Li, C.Y.; Yu, B.; Guo, J.Q.; Li, J. Supramolecular cobalt(II) and copper(II) complexes with Schiff base ligand: Syntheses, characterization and crystal structures. Chin. J. Inorg. Chem. 2016, 32, 913-920.

74. Jia, H.R.; Li, J.; Sun, Y.X.; Guo, J.Q.; Yu, B.; Wen, N.; Xu, L. Two supramolecular cobalt(II) complexes: Syntheses, crystal structures, spectroscopic behaviors, and counter anion effects. Crystals 2017, 7, 247.

75. Zheng, S.S.; Dong, W.K.; Zhang, Y.; Chen, L.; Dong, Y.G. Four salamo-type 3d-4f hetero-bimetallic $\left[\mathrm{Zn}^{\mathrm{II}} \mathrm{Ln}^{\mathrm{III}}\right]$ complexes: Syntheses, crystal structures, and luminescent and magnetic properties. New J. Chem. 2017, 41, 4966-4973. [CrossRef]

76. Hao, J.; Li, L.H.; Zhang, J.T.; Akogun, S.F.; Wang, L.; Dong, W.K. Four homo- and hetero-bismetallic 3d/3d-2s complexes constructed from a naphthalenediol-based acyclic bis(salamo)-type tetraoxime ligand. Polyhedron 2017, 134, 1-10. [CrossRef]

77. Akine, S.; Sairenji, S.; Taniguchi, T.; Nabeshima, T. Stepwise helicity inversions by multisequential metal exchange. J. Am. Chem. Soc. 2013, 135, 12948-12951. [CrossRef] [PubMed]

78. Hao, J.; Liu, L.Z.; Dong, W.K.; Zhang, J.; Zhang, Y. Three multinuclear Co(II), Zn(II) and Cd(II) complexes based on a single-armed salamo-type bisoxime: Syntheses, structural characterizations and fluorescent properties. J. Coord. Chem. 2017, 70, 1-30. [CrossRef]

79. Hao, J.; Li, X.Y.; Zhang, Y.; Dong, W.K. A reversible bis(Salamo)-based fluorescence sensor for selective detection of $\mathrm{Cd}^{2+}$ in water-containing systems and food samples. Materials 2018, 11, 523. [CrossRef] [PubMed]

Sample Availability: Samples of the compounds are available from the authors.

(c) 2018 by the authors. Licensee MDPI, Basel, Switzerland. This article is an open access article distributed under the terms and conditions of the Creative Commons Attribution (CC BY) license (http:/ / creativecommons.org/licenses/by/4.0/). 